\title{
Innovative collaborative instructional strategies: it's effect on secondary school students' achievement in biology as moderated by verbal ability
}

\author{
Saheed Adejimi ${ }^{1}$, Wenceslas Nzabalirwa ${ }^{1}$ and William Shivoga ${ }^{2}$ \\ ${ }^{1}$ University of Rwanda, Rwanda \\ ${ }^{2}$ Masinde Muliro University of Science and Technology, Kakamega, Kenya
}

Education is changing rapidly. Schools are gradually shifting away from the traditional mode of instruction and toward a more active model of learning, in which students are collaborating on projects in small groups and then sharing their work with the class. Africa cannot afford to be left behind in this change. Though collaborative teaching and learning are quite popular in Africa, its variants/forms, consensus group and cooperative reflective journal writing are not. The effect of collaborative instructional strategies (consensus group and cooperative reflective journal writing) on students' achievement in biology as moderated by verbal ability was determined in this study. Three hundred five senior secondary school II students from two local governments' area within Ibadan Metropolis participated in the study. The Students' Biology Achievement Test (SBAT) and the Students' Verbal Ability Test (SVAT) were the main data collection tools used for this study. Data generated were analysed using Analysis of Covariance (ANCOVA) and Bonferonni post hoc test. Results show that both forms of collaborative instructional strategies improved students' achievement in biology. Results showed that students exposed to the cooperative reflective journal writing achieved more in biology followed by students in the consensus group strategy. Collaborative strategy can be a feasible alternative approach to teaching biology as it fairly addresses issues of interaction in the classroom. This has helped students develop their communication and also improve their socialisation skills in the classroom and beyond.

\author{
ARTICLE DETAILS \\ LUMAT General Issue \\ Vol 9 No 1 (2021), 495-517 \\ Received 28 August 2020 \\ Accepted 26 May 2021 \\ Published 21 June 2021 \\ Pages: 23 \\ References: 72 \\ Correspondence: \\ jimmysaheed@gmail.com \\ https://doi.org/10.31129/ \\ LUMAT.9.1.1397
}

Keywords: Achievement, collaborative, consensus, cooperative reflective journal writing, verbal ability

\section{Introduction}

Teaching and learning is a key aspect of any educational process. It aims is to enrich the learners experience, skills and overall development to function or integrate into the society. Since students' learning is the fulcrum upon which any teaching/learning activity is anchor upon, it behoves that the teaching strategies to be employed should foster students' learning. The strategy employed in the classroom by the teacher can either improve or mar the creative ability of the students. However, in most science classrooms, the strategy employed by teachers only encouraged rote learning and regurgitation of facts, which does not allow for creativity, (Usman, 2008). This, 
according to Adepitan (2003) and Okoronka (2004), is the way sciences are being taught in Nigeria schools does not allow the students to derive a maximum benefit, because science instructions are mostly teacher-centred. This has led to many students facing learning difficulties and not performing to their optimised level in the classrooms. This strategy termed variously as lecture, expository, traditional or conventional strategy, do not foster interaction between teacher-students and between students-students, (Olatoye, Aderogba, \& Aanu, 2011).

Azubuike, (2012), Cepni, Tas and Kose (2006), Okoli and Egbunonu (2012) posited that the use of traditional instructional approach in teaching only allowed students to understand the subject content at the knowledge level as they usually memorised the science phenomena, concepts and theories without understanding the real meanings. Wood and Gentile (2003) opined that these traditional methods of conveying knowledge have been shown to be relatively ineffective on students' ability to master and then retain important concepts. Learning through these methods is passive rather active and does not tend to foster critical and creative thinking and collaborative problem-solving (Olatoye, et al, 2011) in students. As a consequence, students do not have a good comprehension of the science concepts being taught and this leads to poor performance. It is now being acknowledged that there are better ways to learn than through the traditional methods of instruction (Wood \& Gentile, 2003). Stakeholders are now coming to the realisation that students needs and characteristics need to be taking into consideration when planning for a lesson.

Students' academic achievement in biology and any other disciplines is a function of the instructional strategy adopted by teacher in the classroom. According to Azubuike (2012) and Salau (2002), researches have attributed poor performance in public examinations to the instructional delivery approaches adopted by many teachers. They noted that most teachers utilise the traditional instructional delivery approaches. These approaches do not take into cognisance each student peculiarities and in effect do not encourage students' active participation in the lesson. Akale (1990) and Azubuike (2012) averred that the most pronounced and important factor that generally influence students' academic achievement in science is the teacher and the teaching methods adopted in the classroom. In other word, the role of the teacher and the instructional strategy adopted in the classroom is a sine-qua-non to students' achievement.

To stem the tide of poor academic achievement among students in the classroom, the idea of a sage on the stage must give way to a guide on the side. As Brown (1997) 
puts it, effective instruction requires the teacher to step outside the realm of personal experience into the world of the learners. For meaningful learning to occur, the learner must make the commitment to learn and must also be engaged (Akinsola \& Animasahun, 2007). According to Iroegbu (1998), learners tend to derive maximum benefits in learning cognitive skills when the teaching strategy adopted involves the use of a mixture of different methods while at the same time creating an opportunity for the learners to practice skills as a meaningful whole. It means for the students to learn meaningfully and be successful academically, the students must be made actively involved in their learning with the guidance of the teacher.

There had been several attempts made to improve the academic achievement of students in biology through the discoveries and application of innovative, effective and students-centred instructional strategies. Some of these strategies include cooperative learning, reflective journal writing, jigsaw, buzz, concept map, peer tutoring, among others. These strategies had all proven to be capable of improving the academic achievement of students, but more needs to be done. These strategies as according to Ukoh and Adejimi (2018), have the potential of enhancing positive interactions and friendship among students. In order to explore further the effects of innovative student-centred teaching approach on students' achievement in biology, this study, therefore, seeks to determine the effect of two innovative, collaborative instructional strategies (consensus group and cooperative reflective journal writing) on students' achievement in biology, as moderated by verbal ability.

\subsection{Theoretical framework}

The study is premised on the Social Interdependent Theory (SIT) approach to teaching and learning. The SIT was first known and called theory of Cooperation and Competition and was developed by Morton Deutsch (1949a, 1949b, 1973 \&1985). It was further elaborated by David W. Johnson (Johnson \& Johnson, 1989). The historical roots of social interdependence theory can be traced to a shift from mechanistic to field theories in physics (Deutsch, 1968). This shift especially influenced the emerging school of gestalt psychology at the University of Berlin in the early 1900 s (Johnson, 2003). Building on the principles of Gestalt psychology, Kurt Lewin proposed that the essence of a group is the interdependence among members which results in the group being a "dynamic whole" so that a change in the state of any member or subgroup changes the state of any other member or subgroup (Lewin, 1935; 1948). 
Lewin (1935) further states, group members are made interdependent through common goals. As members perceive their common goals, a state of tension arises that motivates movement toward the accomplishment of the goals. Morton Deutsch (1949; 1962) extended Lewin's notions by examining how the tension systems of different people may be interrelated. This (aroused tension) forms the basis of the SIT. As Johnson and Johnson (2005) stated, for interdependence to occur, there must be more than one person or entity involved and the people or entities must influence each other, in that a change in the state of one causes a change in the state of the others. This influence reflects in the immediate situation, as each person's behavior is determined by how the situation is perceived, rather than by objective or historical factors (i.e., the principle of contemporaneity). As a person's life space is dynamic (not static), so that, as individuals interact and events occur, each individual's perceptions of the situation change. Within this life space, people's behaviour is motivated by states of tension that arise as they perceive their desired goals. It is this tension that motivates movement toward the accomplishment of the goals. The perception of common goals in conjunction with the joint motivation to achieve them is the source of interdependence among group members.

Social interdependence exists when the accomplishment of each individual's goals is affected by the actions of others (Deutsch 1949a, 1962; Johnson 1970, 2003; Johnson \& Johnson 1989; 2005). There are two types of social interdependence; positive (cooperation) and negative (competition) interdependence. Positive interdependence will support the attainment of a group goal, while negative interdependence will hinder it.

Deutsch (2006) stated, positive interdependence occurs when the goals are linked in such a way that amount or probability of an individual attaining his/her goal is positively related with the amount or probability of another reaching his/her goal. Negative interdependence occurs when the goals are linked in such a way that the amount or probability of an individual attaining his/her goal is negatively related with the amount or probability of another reaching his/her goal. Deutsch (1949, 1962) opined that positive interdependence creates the psychological processes of substitutability (i.e., the degree to which actions of one person substitute for the actions of another person), positive cathexis (i.e., the investment of positive psychological energy in objects outside of oneself, such as friends, family, and work), and inducibility (i.e., the openness to being influenced by and to influencing others). 
Negative interdependence tends to create non-substitutability, negative cathexis, and resistance to influence.

In essence, positive interdependence will lead to healthy rivalry (promotive interaction) among students which will, in turn, improve students' achievement; negative interdependence will lead to unhealthy rivalry (oppositional or contrient interaction) among students which may leads to poor achievement in trying to better each other. Promotive interaction is the efforts put in by individuals in assisting each other to complete tasks, achieve, or produce in order to reach the group's goals. It consists of number of factors/variables; mutual help and assistance, exchange of needed resources, effective communication, mutual influence, trust and constructive management of conflict. In other word, Oppositional interaction is individuals in discouraging and obstructing each other's efforts to complete tasks, achieve, or produce in order to reach their goals; individuals focus both on increasing their own productivity and on preventing any other person from producing more than they do. It consists of such variables as obstruction of each other's goal achievement efforts, tactics of threat and coercion, ineffective and misleading communication, distrust, and striving to win in conflicts (Johnson, Johnson, \& Smith, 2007).

The basic premise of social interdependence theory is that the ways in which participants' goals are structured determine how they interact, and the interaction pattern determines the outcomes of the situation (Deutsch, 1949, 1962). This structure and interaction forms the bases upon which collaborative instructional strategies are derived. A positively structured interdependence leads to promotive interaction which in turn leads to high effort to achieve, positive relationships and psychological health, while a negatively structured interdependence leads to oppositional interaction which leads to low effort to achieve, negative relationships and psychological illness.

\subsection{Literature review}

As society advances more into the knowledge age, it is becoming increasingly obvious that cognitive/knowledge work is more effective when done in collaboration with other students. Consensus is a form of collaborative, non-coercive decision-making strategy that allows everybody express their opinion and feels they are heard. It is a creative and unique way of reaching agreement between all members of a group. It is neither compromise nor unanimity - but aims to pull together everyone's best ideas and key concerns - a process that often results in surprising and creative solutions, 
inspiring both the individual and the group as a whole (seedsforchange.org.uk). According to Sartor and Young Brown (2004), consensus is a conscious agreement by everyone. The procedure that leads to consensus-or at least attempts to find consensus is called -the "consensus process". It is characterised by listening, sharing, trusting and respecting the opinions of one another.

Consensus is a decision-making model utilised by prehistoric tribes and adopted by organisations, communities, and groups in coming to a unanimous decision, one that works for everyone (Schutt, 2001). Consensus confers many advantages to those engages in it; promote shared authority and responsibility in making decisions, enhances students' self-expression, encourages full student participation, stimulates creative decision-making, nurtures the development of a conscious community, shows that education can be a practice of freedom, and helps learners to form good self-concepts, heighten their level of engagement, and improve their ability to apply learning in new contexts (Blinne, 2013; Bruffee, 1999; Freire, 1998; Hooks, 1994; MacDougall, 2013; Mitchell, Foulger, Wetzel \& Rathkey 2009; Sartor \& Young Brown, 2004; Wolk, 1998).

There is not much study with which to support the result from the study with, since little study has been carried out on the effect of consensus group instructional strategy on students' achievement in biology. According to Sartor and Young Brown (2004), the major factor militating against the use of consensus, is it effect on academic performance or scores on standardised tests. This concern was echoed by Fetalvero (2017), when he stated that there was no comparable empirical study with which to compare his result with as at then. Nevertheless, Fetalvero (2017) reported, despite the fact that there was no significant difference in the academic achievement of students exposed to Consensus-Based Education (CBE) and Conventional Education (CE), the consensus-based education showed the prospect of improving students' academic achievement in bioenergetics. He submitted that the effectiveness of CBE over CE became obvious when the students gained scores were categorised into a fivepoint interval and an item-by-item analysis conducted across the achievement scores grouped by topics and cognitive domain. The students in the CBE group outperform the students in the CE group; this confirms the prospect of CBE over CE.

Cooperative reflective journal writing combines the features of both cooperative learning and reflective journal writing strategies which allows students to reflect together as they learn in a cooperative manner or environment. Ige and Adu (2016) define cooperative reflective journal writing as a strategy that involves students 
working cooperatively as they reflect on classroom tasks. It, therefore, means that a cooperative reflective journal allows students to reflect cooperatively in the classroom as they learn together in a group. Cooperative learning is arguably one of the most researched strategies of all instructional strategies. It is a form of collaborative work that enables students to work together within a small group to maximise each other potential. It is a pedagogical approach that helps students to gain and create both academic and social relationships as well as to accomplish shared goals, (Johnson, D.W \& Johnson, 2002; Lou, Abrami, Spence, Poulsen, Chambers \& d'Apollonia, 1996; Slavin, 1996).

The success achieved in the implementation of cooperatively learning and reflective journal writing respectively in promoting students' achievement prompted some researchers to combine cooperative learning and reflective journal writing to seek the effects on students learning. Ige and Adu (2016) reported that cooperative reflective journal writing improves students' achievement in biology more compare to individualised reflective journal writing and conventional instructional strategies. Also, Güvenç (2010) reported that the achievement of students taught with cooperative learning combine with reflective journal writing better those of students taught with cooperative learning alone. These reports bring to the fore that, when strategies are combined they produce a better result than one single strategy.

Asides teaching strategies that have effect on students' academic achievement, students verbal prowess (verbal ability) can also have an effect on students' academic achievement. Given the nature of the two collaborative strategies (consensus group and cooperative reflective journal writing), verbal ability can greatly affect the achievement of students when exposed to both types of strategies. Verbal ability is an important element in human intelligence (Widhiarso \& Haryanta, 2016). It is the most compelling feature of school learning and is automatically assessed (Richard \& Giovanni, 1990), repeatedly consciously and/or unconsciously. According to Adegbile and Alabi (2007), it may show a significant level of relationship with students' grades. It has a strong connection with many academic disciplines like reading, writing, speaking, mathematics and sciences (Rinderman, Michou \& Thompson, 2011; Walker, Green, Hart, \& Carta, 1994).

Several studies have shown that there is a connection between students' verbal ability and their academic achievement. Awofala, Balogun and Olagunju (2011), Corengia, Pita, Mesurado and Centeno (2013), Ige and Adu (2016), Vilia, Candeias, Neto, Franco and Melo (2017) and Tzu-Ling Wang (2008) in their respective studies 
all affirmed that students' verbal ability has an effect on their academic achievement, that is students with high verbal ability achieve higher than students with low verbal ability. On the other hand, results from the studies by Ezenandu (2012), Maduabuchi (2006) and Makinde (2004) all reported that students' verbal ability has no effect on students' academic achievement. In view of divergent reports on the importance of verbal ability on students' achievement, this study will further investigate the variable with respect to consensus group and cooperative reflective journal writing on students' achievement in Biology.

\subsection{Aim of the Research}

Historically, biologists have identified teaching as cooperative behaviour in which the "teacher" changes his or her actions to aid a naive "student" in acquiring knowledge or skills (Caro \& Hauser, 1992). But knowledge acquisition has been reduced to a process by which information is poured from a jug (teacher) into receptacles (students). This situation has made the students passive in their learning and negatively impacted their achievement in biology. Biology is a 'simple' and an important subject in the daily living of man, literature has revealed that students' performance in biology on the Senior Secondary School Certificate Examination (SSSCE) has been consistently poor, and this is mostly attributed to the instructional strategy adopted by the teacher which is teacher centred.

Education is changing rapidly. Schools are shifting away from the traditional mode of instruction and toward a more active model of learning, in which students are collaborating on projects in small groups and then sharing their work with the class, (eSchool News, 2017). This student-centred strategy has engendered the spirit of cooperation among the students, and subsequently leads to an improvement in their academic achievement in biology. This study, therefore, seek to determine the effect of two innovative collaborative instructional strategies (consensus group and cooperative reflective journal writing), with the moderating effect of verbal ability on students' achievement in biology. No known study has been conducted on the effect of consensus on students' achievement in biology or any other discipline in Nigeria, while the only known study on the effect of cooperative reflective journal writing on students' achievement in biology was conducted in 2016 by Ige and Adu. 


\subsection{Hypotheses}

The following three null hypotheses will be tested:

1. There is no significant main effect of treatments on students' achievement in biology

2. There is no significant main effect of verbal ability on students' achievement in biology

3. There is no significant interaction effect of treatment and verbal ability on students' achievement in biology

\subsection{Scope}

Six co-educational Senior Secondary Schools were purposively selected from Ibadan North and Ibadan North West Local Government areas of Oyo State Nigeria. Intact class of one arm each was used in all selected schools. The schools were randomly assigned to treatment and control groups. The study focused on the effects of consensus group and cooperative reflective journal writing instructional strategies with moderating effect of verbal ability on students' achievement in some concepts in Biology. The topics that were treated during the course of the study were ecological management and nutrient cycling in nature.

\section{Materials and methods}

\subsection{Research Instruments}

The following instruments were used to collect data for the study:

1. Students' Biology Achievement Test (SBAT)

2. Students' Verbal Ability Test (SVAT)

3. Teacher's Instructional Guide on Consensus Group Instructional Strategy (TIGCGIS)

4. Teacher's Instructional Guide on Cooperatively Reflective Journal Writing Instructional Strategy (TIGCRJWIS)

5. Teacher's Instructional Guide on Conventional Instructional Strategy (TIGCIS) 
Students' Biology Achievement Test

Students' Biology Achievement Test (SBAT) was developed by the researchers to measure the achievement level of the students on the concepts of ecological management and nutrient cycling in nature in biology before and after the implementation of the intervention. The instrument consisted of forty (40) multiple choice questions with options A - D. Each correct answer in SBAT was rewarded one mark; to make a total of 40 marks. The face validity of the instrument was done by science education experts to determine its suitability and the reliability coefficient of 0.74 was obtained using Kuder-Richardson formula- 20 (KR-20). The choice of KR20 was premised on the inequality in the level of difficulty of the items in the Biology achievement test.

Students' Verbal Ability Test (SVAT)

Students' Verbal Ability Test (SVAT) was adapted from the Australian Council for Educational Research (ACER) to tests students' verbal ability. It has gone through several modifications and revalidation for use by some Nigerian authors (Abimbade, 1987: Aimunmondion, 2008: Awofala, Balogun \& Olagunju, 2011: Ezenandu, 2012: Fakeye 2006: Ige \& Adu, 2016: Maduabuchi, 2002: Olaboopo, 1999) since its first introduction into the Nigerian education system by Obemeata in 1974. However, the researchers re-validated the test to ascertain its suitability for this study. The SVAT was tested in trials on twenty (20) senior secondary school II students in a school that was not selected for the main study. The data collected were analysed using KuderRichardson formula 20 (Kr2O), and a reliability of 0.78 was obtained. Kr2O was used because of the inequality of the difficulty level of the items in the SVAT. The SVAT was administered to the participants once before the treatment began.

Teachers' Instructional Guides

Teachers' instructional Guide on Consensus Group Instructional Strategy (TIGCGIS), Teachers' Instructional Guide on Cooperative Reflective Journal Writing Instructional Strategy (TIGCRJWIS) and Teachers' instructional Guide on conventional method (TIGCM) are the lesson notes, which were prepared weekly for the six weeks of the treatment for the study. The duration for each lesson was 80 minutes (double periods). The essence of these instruments was to guide the research assistants (teachers) on the use of steps and procedure followed during the treatment. 


\begin{tabular}{|c|c|}
\hline Treatments & Procedures \\
\hline $\begin{array}{l}\text { Consensus } \\
\text { Group } \\
\text { Instructional } \\
\text { Strategy }\end{array}$ & $\begin{array}{l}\text { Division: Divide a class into small groups, usually of about } 5 \text { learners } \\
\text { Provision (Assignment) of task: Assigned a task, usually designed ahead of time, for the small } \\
\text { groups to work on } \\
\text { Deliberation takes place among group members } \\
\text { Group members reach a consensus } \\
\text { Teacher reconvenes students into a plenary session to hear the reports from the small groups } \\
\text { and negotiate a consensus of the class as a whole } \\
\text { Lead students to compare the class's plenary consensus with the current consensus of the } \\
\text { knowledge community in order to arrive at a better consensus/decision/judgement } \\
\text { Evaluate explicitly the quality of students' work. }\end{array}$ \\
\hline $\begin{array}{l}\text { Cooperative } \\
\text { Reflective } \\
\text { Journal Writing } \\
\text { Instructional } \\
\text { Strategy }\end{array}$ & $\begin{array}{l}\text { Teacher presents the topic } \\
\text { Teacher tells the students the task to be done } \\
\text { Teacher highlights the major idea within the topic to be taught } \\
\text { Teacher groups the students in five-member heterogeneous teams by gender only. } \\
\text { Each group appoints a leader and a clerk } \\
\text { Teacher gives group some few minutes to review the lesson and share their views } \\
\text { The team writes a group journal based on the following guidelines: } \\
\text { What question do you have about this lesson? } \\
\text { What have you learned in the lesson? } \\
\text { What areas did you find difficult? } \\
\text { What areas did you find interesting? } \\
\text { How do you think this lesson will be useful for you to apply outside the classroom? } \\
\text { Teacher collects the group journal for compilation of entries } \\
\text { Raised group questions were thrown to the groups for answer in the next lesson } \\
\text { Students learning were evaluated based on group entries. }\end{array}$ \\
\hline $\begin{array}{l}\text { Conventional } \\
\text { Strategy }\end{array}$ & $\begin{array}{l}\text { The teacher introduces the lesson by asking questions based on the students' previous } \\
\text { knowledge. } \\
\text { Teacher presents instructional aid and discusses the contents of the lesson with the students. } \\
\text { Teacher directs students to write the chalkboard summary in their notebooks. } \\
\text { Teacher evaluates the lesson by asking students some questions in class, later on } \\
\text { homework/assignment. }\end{array}$ \\
\hline
\end{tabular}

\subsection{Research design}

This study adopted a quantitative pretest-posttest, control group quasi-experimental design involving a 3X2 factorial matrix. This design was employed because the participants were from intact classes in a natural school setting where random assignment was not possible, and the distraction of class structure was avoided to the minimum. The treatment was the instructional strategy at three levels (consensus group, cooperative reflective journal writing and conventional method). The moderator variable was verbal ability at two levels (low and high). Students' achievement in biology was the dependent variable. 


\subsection{Sampling and Sampling Technique}

The study population was all the senior secondary school two students within Ibadan metropolis Oyo State, Nigeria. A multistage sampling technique was used to pick 305 students for the study. At the first stage of sampling, two local governments were randomly selected out of the five local governments within the metropolis. At the second stage, three coeducational schools that were distantly located were selected purposively in each of the local government areas to make a total of six schools. This was done in order to avoid or minimise experimental contamination. In all the schools intact classes were used.

\subsection{Schematic Representation of the Design}

\begin{tabular}{|l|l|l|l|}
\hline Groups & Pre-test & Treatment & Post-test \\
\hline $\begin{array}{l}\text { Consensus Group } \\
\text { Instructional Strategy }\left(\mathrm{E}_{1}\right)\end{array}$ & $\mathrm{O}_{1}$ & $\mathrm{X}_{1}$ & $\mathrm{O}_{2}$ \\
\hline $\begin{array}{l}\text { Cooperative Reflective } \\
\text { Journal Writing Instructional } \\
\left.\text { Strategy ( } \mathrm{E}_{2}\right)\end{array}$ & $\mathrm{O}_{3}$ & $\mathrm{X}_{2}$ & $\mathrm{O}_{4}$ \\
\hline $\begin{array}{l}\text { Conventional Method } \\
\text { Instructional Strategy (C) }\end{array}$ & $\mathrm{O}_{5}$ & $\mathrm{X}_{3}$ & $\mathrm{O}_{6}$ \\
\hline
\end{tabular}

Where $\mathrm{O}_{1}, \mathrm{O}_{3}$ and $\mathrm{O}_{5}$ represent the pre-test scores of consensus group strategy $\left(\mathrm{E}_{1}\right)$, cooperative reflective journal writing strategy $\left(\mathrm{E}_{2}\right)$ and conventional method $(\mathrm{C})$, respectively. $\mathrm{O}_{2}$ and $\mathrm{O}_{4}$ are the post-test scores of the treatment groups $\left(\mathrm{E}_{1}\right.$ and $\left.\mathrm{E}_{2}\right)$, and $\mathrm{O}_{6}$ is the post-test of the control group. $\mathrm{X}_{1}$ represents treatment for experimental group one $\mathrm{E}_{1}$ (Consensus Group) $\mathrm{X}_{2}$ represents treatment for experimental group two $\mathrm{E}_{2}$ (Cooperative Reflective Journal Writing) $\mathrm{X}_{3}$ represents treatment for control, group C (conventional method)

\subsection{Study Procedure}

In carrying out the treatment, the following procedure was adopted: During the study, the first week was used to train the research assistants (classroom teachers), the second week used to conduct the pre-tests. Treatment lasted for six weeks utilising the 80 minutes periods. Post-tests were conducted for all groups in the last week of the study. 


\subsection{Data Analysis}

The post-test achievement scores were subjected to a two-way analysis of covariance (ANCOVA) using the pre-test scores as covariates. Analysis of covariance is used to test the main and interaction effects of categorical variables on a continuous dependent variable, controlling for the effects of selected other continuous variables, which co-vary with the dependent. The control variables are called the "covariates". It's also used to control for factors which cannot be randomised but which can be measured on an interval scale in experimental designs. The ANCOVA reduces experiment error by statistical rather than by experimental procedure (Coolican, 1994). The Bonferroni post hoc test was used to determine which of the groups causes the significant main effect, while the interaction effect was explained by the aid of a graph. The Bonferroni post hoc test was employed in order to be certain that the treatments (consensus group and cooperative reflective journal writing) strategies has positive effects on students' academic achievement in comparison to the conventional mode of teaching.

\section{Results}

\subsection{Hypothesis 1}

There is no significant main effect of treatment on students' achievement in Biology. The summary of this result is given in table 1.

Table 1. Analysis of Covariance (ANCOVA) of Post-Achievement by Treatment and Verbal ability

\begin{tabular}{lllllll}
\hline Source & $\begin{array}{l}\text { Type III Sum } \\
\text { of Squares }\end{array}$ & Df & Mean Square & F & Sig. & $\begin{array}{l}\text { Partial Eta } \\
\text { Squared }\end{array}$ \\
\hline Corrected Model & 6933.707 & 6 & 1155.618 & 220.213 & 0.000 & 0.816 \\
Intercept & 11508.070 & 1 & 11508.070 & 2192.966 & 0.000 & 0.880 \\
Pre-Achievement & 659.273 & 1 & 659.273 & 125.630 & 0.000 & 0.297 \\
Treatment & 769.898 & 2 & 384.949 & 73.355 & $0.000 *$ & 0.330 \\
Verbal ability & 273.710 & 1 & 273.710 & 52.158 & $0.000 *$ & 0.149 \\
Treatment x Verbal ability & 59.905 & 2 & 29.953 & 5.708 & $0.004 *$ & 0.037 \\
Error & 1563.820 & 298 & 5.248 & & & \\
Total & 278635.000 & 305 & & & & \\
Corrected Total & 8497.528 & 304 & & & & \\
\hline R Squared = 0.82 (Adjusted R Squared $=0.81)$ & $*$ denotes significant $p<0.05$ & & \\
\hline
\end{tabular}


Table 1 reveals that there is a significant main effect of treatment on students' achievement in biology $\left(\mathrm{F}_{(2,304)}=73.36 ; \mathrm{p}<0.05\right.$, partial $\left.\eta^{2}=0.33\right)$. The effect size, $33.0 \%$, showed a small effect size. Nevertheless, it showed that there was a statistical difference among students in the treatment groups from the conventional group. Therefore, hypothesis 1a was rejected. In order to explore the magnitude of the significant main effect across treatment groups, the estimated marginal means of the treatment groups were carried out and the result is presented in Table 2.

Table 2. Estimated Marginal Means for Post-Achievement by Treatment and Control group

\begin{tabular}{|c|c|c|c|c|}
\hline \multirow[t]{2}{*}{ Treatment } & \multirow[t]{2}{*}{ Mean } & \multirow[t]{2}{*}{ Std. Error } & \multicolumn{2}{|c|}{ 95\% Confidence Interval } \\
\hline & & & Lower Bound & Upper Bound \\
\hline CGIS & 31.85 & 0.31 & 31.24 & 32.45 \\
\hline CRJWIS & 32.21 & 0.59 & 31.05 & 33.36 \\
\hline CMIS & 27.07 & 0.29 & 26.50 & 27.64 \\
\hline
\end{tabular}

Table 2 reveals that students in the CRJWIS treatment group 2 had the highest adjusted mean score in their post-achievement in biology (32.21), followed by those in the CGIS treatment group 1 (31.85) and their counterparts in the CMIS control group (27.07). To determine which of the groups causes this significant main effect of treatment on students' achievement in biology, the Bonferroni post hoc test is carried out across the groups, while the result is presented in Table 3.

Table 3. Table 3: Bonferroni Post-hoc Analysis of Post-Achievement by Treatment and Control Group

\begin{tabular}{lcccc}
\hline Treatment & Mean & CGIS & CRJWIS & CMIS \\
\hline CGIS & 31.85 & & & $*$ \\
CRJWIS & 32.21 & & & $*$ \\
CMIS & 27.07 & $*$ & $*$ & \\
\hline
\end{tabular}

Table 3 indicates that the post-achievement mean score in biology of students in CRJWIS is not significantly different from those taught with the CGIS but significantly different from those exposed to CMIS. Table 3 also indicates that the difference in the post-achievement mean scores of students exposed to CGIS and their counterparts in the CMIS is significant. This indicates that the significant difference 
revealed by the ANCOVA result is not due to the difference between the treatment groups (CRJWIS and CGIS) but between the treatment groups and the control group as students' post-achievement scores in biology is concerned.

\subsection{Hypothesis 2}

There is no significant main effect of verbal ability on students' achievement in Biology.

The result of the analysis of covariance from Table 1 shows that there was a significant main effect of verbal ability on students' post-test achievement scores in biology $\left(F_{(1,304)}=52.16 ; p<0.05\right.$, partial $\left.\eta^{2}=0.15\right)$. The effect size $15.0 \%$ showed a small effect size. Hypothesis 2 was therefore rejected. This implies that verbal ability has a main significant effect on students' achievement in Biology irrespective of their treatment status.

Table 4. Estimated Marginal Means for Post-Achievement by Verbal ability

\begin{tabular}{lcccc}
\hline Verbal ability & Mean & Std. Error & \multicolumn{2}{c}{$95 \%$ Confidence Interval } \\
& & & Lower Bound & Upper Bound \\
\hline Low & 28.57 & 0.44 & 27.71 & 29.42 \\
High & 32.18 & 0.22 & 31.74 & 32.62 \\
\hline
\end{tabular}

Table 4 reveals that high verbal ability students had higher adjusted mean score in post-achievement in biology (32.18) than their low verbal ability counterparts (28.57). This implies that high verbal ability students have better achievement scores in biology than the low verbal ability students and this difference is significant.

\subsection{Hypothesis 3}

There is no significant interaction effect of treatment and verbal ability on students' achievement in biology

The result from Table 1 revealed that there was an interaction effect of treatment and verbal ability on students' achievement scores in biology $\left(\mathrm{F}_{(2,304)}=5.71, \mathrm{p}<0.05\right.$; partial $\left.\eta^{2}=0.04\right)$. The effect size of 4.0 revealed a small effect size. Hypothesis 3 was rejected. Treatment and verbal ability had a significant effect on students' achievement in biology. An interaction effect is the simultaneous effect of two or more independent variables on at least one dependent variable in which their joint effect is 
significantly greater (or significantly less) than the sum of the parts. The inclusion of an interaction term effect in an analytic model provides the researcher with a better representation and understanding of the relationship between the dependent and independent variables. Further, it helps explain more of the variability in the dependent variable, (Encyclopedia of Survey Research Methods, 2008). The significant interaction effect of the treatments and verbal ability showed that the result of the study was not by chance.

The use of a line graph gives a further illustration of the interaction effect.

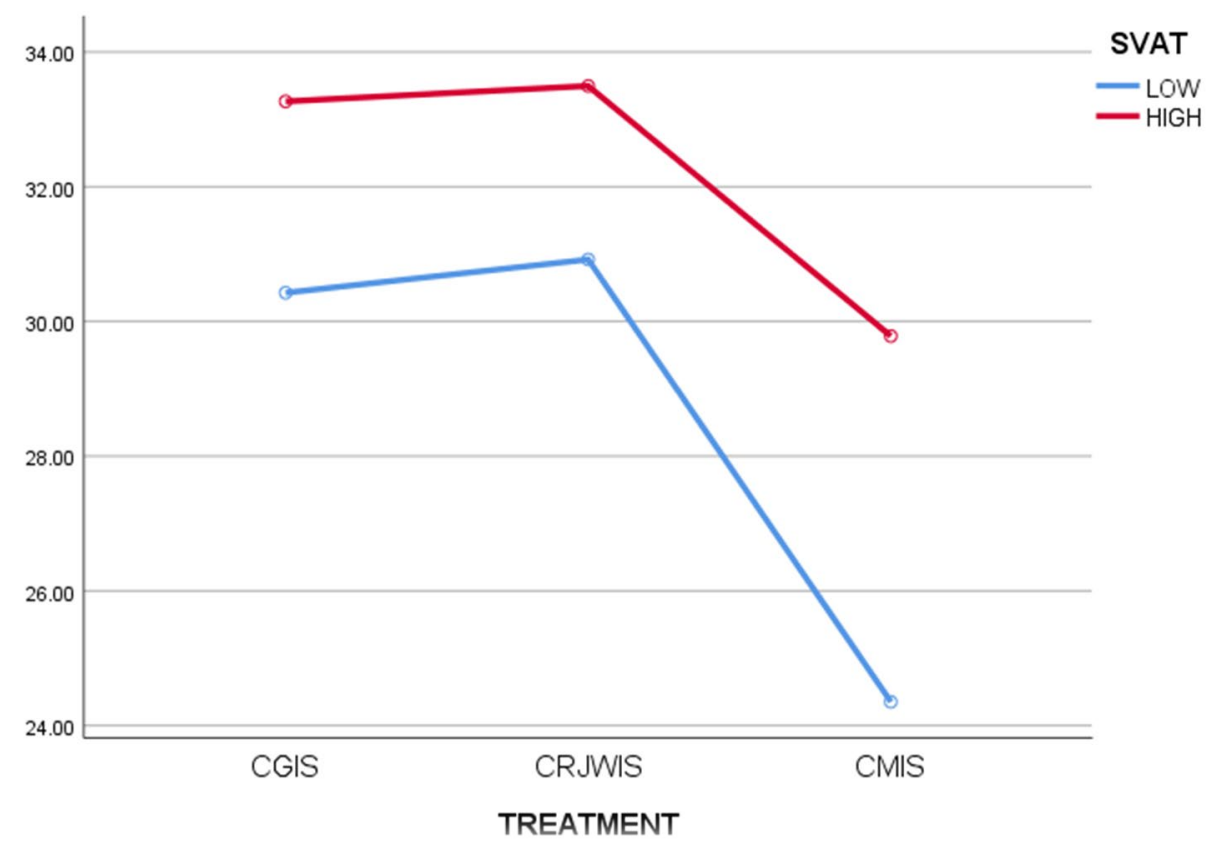

Figure 1. Treatment and verbal ability on students' achievement in biology

Figure 1 revealed that students with high verbal ability achieved better compare to students with low verbal ability regardless of the treatment conditions. Students under the CRJWIS had the highest scores in verbal ability, followed by students under CGIS and students under the conventional method had the least scores in verbal ability. This means that the same set of students achieved more in biology based on their scores in the SVAT.

\section{Discussion}

Collaborative strategies were more effective at improving students' achievement in biology than the conventional method. The effectiveness of collaborative strategy over the conventional method may be due to the fact that the strategy helped the students 
to work collectively and actively participate in their learning activities. Furthermore, the effectiveness of the two modes of collaborative strategy (consensus group and cooperative reflective journal writing) may be attributed to the fact that these strategies enhance students' engagement, communication and listening skills, sharing of ideas, and students are able to arrive to joint decisions or knowledge agreeable to all, which is often superior to an individual decision or knowledge. This finding conform to the findings of (Alvarez, Salavati, Nussbaum \& Milrad, 2013; Awofala, Fatade, \& Ola-Oluwa, 2012; Nneji, 2011; Olabiyi and Awofala, 2019).

Collaborative strategies enhance not only student cognitive skills, which aids longterm retention of learned contents. It also enhances non-cognitive skills like selfconfidence, critical thinking, persuasion, problem-solving, work ethics, time management and leadership traits. In the course of collaborating, each student endeavour to articulate his/her thought and strive to persuade one another of the strength of their argument in order to arrive at a solution to a problem. Since they have to work within a time frame and under a peaceful atmosphere, a leader will be appointed to coordinate the affairs of the group. These assertions are supporting by the findings of (Bezerra, 2018; Hartmann, Toksvang \& Berg, 2015; Petersen, Toksvang, Plovsing \& Berg, 2014). All these skills are required even outside the four walls of the classroom and the school generally.

The studies by Fetalvero (2017) and Ige and Adu (2016) on the effect of ConsensusBased Education and reflectively journal writings on students' achievement in bioenergetics and biology respectively highlighted the effectiveness of these strategies. According to these authors, the incorporation of personal feelings, intuition, experience, wisdom, and insights coupled with reflection helps individual to gain access to multiple sources of information.

Verbal ability had a significant main effect on students' achievement in biology. Students with high verbal ability continuously achieved better than students with low verbal ability. This lend credence to the studies of Adegbile and Alabi (2007), Awofala, Balogun and Olagunju (2011), Ige and Adu (2016) that irrespective of the instructional strategies adopted by the teacher, verbal ability will affect students' achievement. It is against the findings of Ezenandu (2012), Maduabuchi (2006) and Makinde (2004) who all reported that students' verbal ability does not affect their achievement. The findings imply that students should be helped and encouraged to develop their vocabulary, and this can be achieved by exposing them to reading diverse biological 
and/or science texts. Biology and science in general are both expressive and symbolic, as a result, students need to be acquainted with its language.

Students' academic achievement in any subject, biology inclusive is a function of their verbal prowess in the language of that subject. Verbal ability enables students to be able to interpret and present information, thoughts or ideas in a concise, logical and analytical manner which in turn increases their chances to improve performance. This can only be achieved by students who are proficient in the language of the subject. This is supported by the findings of Adegbile and Alabi (2007) who states that students' verbal ability is associated with their grades and Iyamu (2005), who states that verbal ability is important to effective and successful school learning.

There was a significant interaction effect of treatment and verbal ability on students' achievement in biology. The higher the scores of students in the verbal ability test, the higher their scores in the biology achievement test. This result is supported by the finding of Adegbile and Alabi (2007), Awofala, Balogun and Olagunju (2011) who reported a significant interaction between treatment and verbal ability on students' achievement, but in contrast to the findings of Ezenandu (2012) and Ige and Adu (2016) who reported no interaction effect between treatment and verbal ability on students' achievement.

\section{Conclusion and Recommendations}

The study confirmed that the application of collaborative instructional strategy has the potential of improving students' achievement in biology. The consensus group and cooperative reflective journal writing instructional strategies were both effective in improving students' achievement in biology over the conventional strategy. The two strategies both enhance students' engagement, communication, listening and interpersonal social skills. Students' verbal ability also play a vital role within the two strategies since students have to communicate with each other in their respective groups. Students with high verbal ability were able to express their thoughts and feeling within the group and were able to seek solutions where they encountered problems, while the low verbal ability students were not able to express their thoughts and feeling and by so doing may not get solution to their problems. The importance of this present study is its addition to the number of innovative teaching approaches available biology teachers in the teaching and learning of biology in Nigeria secondary schools.

Based on the findings from the study, the following recommendations were made, 
1. There is need to popularise the use of both form of collaborative instructional strategy among secondary school teachers in the teaching of Biology.

2. Biology teachers should be encouraged to adapt these strategies to their classroom setting in order to improve the achievement of their students in Biology.

3. Government and teachers' professional bodies should endeavour to expose Biology teachers to the use of these strategies through seminars and workshops and in teacher training institutions to facilitate better performance of secondary school Biology students.

4. The medium of instruction used in the classrooms should be geared towards easy assimilation by all students.

5. Adequate caution should be taken during group discussion in order for students not to derail from the objectives of the lesson

6. Also, teacher should endeavour to ensure the participation of all students during groups' discussion.

\section{References}

Abimbade, A. (1987). Effects of the use of electronic calculator on outcomes of mathematics instruction. Unpublished PhD Thesis, Department of Teacher Education, University of Ibadan.

Adegbile, J.A and Alabi, O.F. (2007). Effects of verbal ability on second language writers' achievement in essay writing in English language. International Journal of African \& African American Studies 6(1), 61-67.

Adepitan, J. O. (2003). Pattern of enrolment in physics and students' evaluation of the contributory factors in Nigerian colleges of education. African Journal of Educational Research, 2: 136-146.

Aimunmondion M.C. (2008). Effects of thought-flow knowledge and shared reading instructional strategies on senior secondary school students' achievement in English reading comprehension and summary writing. Post Field Seminar Paper Presented at the Joint Staff/Higher Degree Students Seminar Series Department of Teacher Education, University of Ibadan, Ibadan.

Akale, M. A.G. (1990). Teachers and student factors in the implementation of (STM) curricular objectives of the 90s. Science Teachers Association of Nigeria, 31st Annual Conference Proceedings, 107-112.

Akinsola, M.K and Animasahun, I.A. (2007). The effect of simulation-games environment on students' achievement in and attitudes to mathematics in secondary schools. The Turkish Online Journal of Educational Technology - TOJET, 6(3) Article 11

Alvarez, C, Salavati, S, Nussbaum, M and Milrad, M. (2013). Collboard: Fostering new media literacies in the classroom through collaborative problem solving supported by digital pens and interactive whiteboards. Computer and Education, 63, 368-379. DOI: 
Awofala, A.O.A, Balogun, T.A, Olagunju, M.A. (2011). Effects of three modes of personalisation on students' achievement in mathematical word problems in Nigeria. International Journal for Mathematics Teaching and Learning, Available at http://www.cimt.plymouth.ac.uk/journal/awofala.pdf.

Awofala, A.O.A, Fatade, A.O and Ola-Oluwa, S.A. (2012). Achievement in cooperative versus individualistic goal-structured junior secondary school Mathematics classrooms in Nigeria. International Journal of Mathematics Trends and Technology, 3(1)

Azubuike, E. N. (2012) Effect of peer tutoring instructional strategy on achievement in biology of senior secondary school slow learners in Anambra State. An Unpublished Master's Thesis Submitted to the Department of Science Education Faculty of Education Nnamdi Azikiwe University, Awka

Bezerra, J de Melo. (2018). Collaborative testing strategies in a computing course. $15^{\text {th }}$ International Conference on Cognition and Exploratory Learning in Digital Age.

Blinne, K. C. (2013). Start with the syllabus. HELPing learners learn through class content collaboration. College Teaching, 61, 41-43.

Brown B.L (1997). New Learning Strategies for generation. Eric Digest No. 184

Bruffee, K. A. (1999). Collaborative Learning: Higher Education, Interdependence, and the Authority of Knowledge. (2nd ed.) Baltimore, Md.: Johns Hopkins University Press.

Caro, T. M., \& Hauser, M. (1992). Is there teaching in nonhuman animals? The Quarterly Review of Biology, 67, 151-174.

Cepni, S., Tas, E., and Kose, S. (2006). The effects of computer-assisted material on students' cognitive levels, misconceptions and attitudes towards Science. Computers and Education, 46(1), 192-205.

Coolican, H. (1994). Research methods and statistics in psychology, $2^{\text {nd }}$ edition. Hodder and Stoughton.

Corengia, A, Pita, M, Mesurado, B, and Centeno, y A. (2013). Predicting academic performance and attrition in undergraduate students. Liberabit. Revista de Psicologia, 19(1), 101-112.

Deutsch, M. (1949a). An experimental study of the effects of cooperation and competition upon group processes. Human Relations, 2, 199-231.

Deutsch, M. (1949b). A theory of cooperation and competition. Human Relations, 2, 129-151.

Deutsch, M. (1962). Cooperation and trust: Some theoretical notes. In M. R. Jones (Ed.), Nebraska symposium on motivation (pp. 275-319). Lincoln: University of Nebraska Press.

Deutsch, M. (1968). Field theory in social psychology. In G. Lindzey \& E. Aronson (Eds.). The handbook of social psychology (2nd ed., Vol. 1, pp. 412-487). Reading, MA: Addison Wesley.

Deutsch, M. (1973). The resolution of conflict: Constructive and destructive processes. New Haven, CT: Yale University Press.

Deutsch, M. (1985). Distributive justice: A social psychological perspective. New Haven, CT: Yale University Press.

Deutsch, M. (2006). Cooperation and competition. In M. Deutsch, P. T. Coleman, \& E. C. Marcus (Eds.), The Handbook of Conflict Resolution: Theory and practice (pp. 23-42). San Francisco: Jossey-Bass.

Encyclopedia of Survey Research Methods. (2008) Ed. by Paul J. Lavrakas. Los Angeles: Sage, 2 vols

eSchool News (2017). Five challenges for the collaborative classroom-and how to solve them. eSchool News white paper sponsored by ELMO, 1-8. http://www.eSchoolNews.com 
Ezenandu, P.E. (2012). Effects of literature circles and scaffolding instructional strategies on senior secondary school students' achievement and attitude to prose literature in English. A thesis in the Department of Teacher Education, submitted to the Faculty of Education in partial fulfilment of the requirement for the Degree of Doctor of Philosophy of the University of Ibadan.

Fakeye, D.O. (2006). Componential analysis as a model of ESL vocabulary instruction. African Journal of Educational Research, 10(1-2), 14-24.

Fetalvero, E.G (2017). Consensus-based education: its effect on college students' achievement in bioenergetics as moderated by gender and learning styles. Journal of Baltic Science Education, 16(4), 533-548.

Freire, P. (1998). Pedagogy of freedom: Ethics, democracy, and civic courage. Lanham: Rowman \& Littlefield Publishers, Inc.

Güvenç, H. (2010). The effects of cooperative learning and learning journals on teacher candidates' self-regulated learning. Kuram ve Uygulamada Eğitim Bilimleri / Educational Sciences: Theory \& Practice, 10(3), 1477-1487.

Hartmann, J.P, Toksvang, L.N \& Berg, R.M.G. (2015). Collaborative teaching strategies lead to retention of skills in acid-base physiology: a 2-yr follow-up study. Advances in Physiology Education, 39, 120-121, DOI: https://www.doi.org/10.1152/advan.00167.2014

Ige, T.A and Adu, K.E. (2016). Effects of individualised and cooperative reflective journal writing strategies on secondary school students' achievement in Biology in Kwara State, Nigeria. British Journal of Education, Society \& Behavioural Science, 15(4), 1-12.DOI: https://www.doi.org/10.9734/BJESBS/2016/24699

Iroegbu, T. O (1998) Problem based learning, numerical ability and gender and line graphic skills at Senior Secondary Physics in Ibadan. An unpublished Ph.D. Thesis of University of Ibadan.

Iyamu, E.O.S. (2005). Relationship between verbal ability and students' achievement in secondary school social studies in southern Nigeria. Language in India, 5(2), 1-7, www.languageinindia.com/feb2005/verbalabilitynigeria.html

Johnson, D. W. (1970). The social psychology of education. New York: Holt, Rinehart \& Winston.

Johnson, D.W. (2003). Social Interdependence: Interrelationships among Theory, research, and practice. American Psychologist, 58(11) 934-945.

Johnson, D. W. and Johnson, R. T. (1989). Cooperation and competition: Theory and research. Edina, MN: Interaction.

Johnson, D. W., and Johnson, R.T (2002). Learning together and alone. Overview and metaanalysis. Asia Pacific Journal of Education, 22, 95-105.

Johnson, D. W., and Johnson, R.T (2005). New developments in social interdependence theory. Genetic, Social, and General Psychology Monographs, 131(4), 285-358. DOI: https://doi.org/10.3200/MONO.131.4

Johnson, D.W., Johnson, R.T., and Smith, K. (2007). The state of cooperative learning in postsecondary and professional settings. Educ. Psycho Rev 19, 15-29. DOI; https://www.doi.org/10.1007/s10648-006-9038-8

Lewin, K. (1935). A dynamic theory of personality. New York: McGraw-Hill.

Lewin, K. (1948). Resolving social conflicts. New York: Harper.

Lou, Y, Abrami, P, Spence, I, Poulsen, C Chambers, B and d'Apollonia, S. (1996). Within-class grouping: a meta-analysis. Review of Educational Research, 66, 423-458.

MacDougall G. (2013). Student-to-student collaboration and coming to consensus. Science Scope, $37(3), 59-63$. 
Maduabuchi, N. (2002). Methods of teaching vocabulary in secondary schools. Unpublished M.Ed Project, University of Ibadan.

Maduabuchi, H.C. (2006). Effects of literature circle and conversational learning strategies on students; comprehension of poetry. Ebonyi State University Journal of Education, 4(2), 184-194.

Makinde, S.O. (2004). Relative effects of oral and written literature models on students' achievement in Yoruba composition writing in selected schools in Ogun State, Nigeria. PhD Thesis, Dept. of Teacher Education, University of Ibadan.

Mitchell, S., Foulger, T. S., Wetzel, K., \& Rathkey, C. (2009). The negotiated project approach: project-based learning without leaving the standards behind. Early Childhood Education Journal, 36, 339-346.

Nneji, L. (2011). Impact of framing and team assisted individualised instructional strategies students' achievement in Basic Science in the North Central Zone of Nigeria. Knowledge Review, 23(4), 1-8.

Obemeata, J.O. (1974). Predictive validity of intelligence tests M, ML and MQ. African Journal of Educational Research, 1(2), 205-211.

Okoli, J. N., \& Egbunonu, R. N. (2012). Effect of blended learning on senior secondary school students' achievement in biology. International Journal of Education Research and Development (EJERD), 4(1), 91-97.

Okoronka, A. U. (2004). Model based instructional strategies as determinants of students learning outcomes in secondary physics. Unpublished PhD Thesis, University of Ibadan. Ibadan.

Olabiyi, O.S. and Awofala, A.O.A. (2019). Effect of cooperative learning strategy on senior secondary school students' achievement in woodwork technology. Acta Didactica Napocensia, 12(2), 171-182, DOI: https://www.doi.org/10.24193/adn.12.2.13

Olaboopo, J.O (1999). Effect of error treatment model-based and skill-based instructional strategies on attitude, motivation and achievement in English composition in Senior Secondary Schools in Ibadan. Ph.D Thesis of the University of Ibadan.

Olatoye, R.A., Aderogba, A.A., \& Aanu, E.M. (2011). Effect of cooperative and individualised teaching methods on senior secondary school students' achievement in organic chemistry. Pacific Journal of Science and Technology, 12(2), 310-319.

Petersen, M.W, Toksvang, L.N, Plovsing, R.R \& Berg, R.MG. (2014). Collaborative strategies for teaching common acid-base disorders to medical students. Advances in Physiology Education, 38, 101-103, DOI: https://www.doi.org/10.1152/advan.00106.2013

Richard F. Schmid and Giovanni Telaro (1990) Concept Mapping as an Instructional Strategy for High School Biology. The Journal of Educational Research, 84(2), 78-85, DOI:

https://www.doi.org/10.1080/00220671.1990.10885996

Rinderman, H, Michou, C.D and Thompson, J. (2011). Children's writing ability: Effects of parent's education, mental speed and intelligence. Learning and Individual Differences, 21, 562568. DOI: https://www.doi.org/10.1016/j.lindif.2011.07.010

Salau, M.O. (2002). Effects of class size on achievement of different ability groups in mathematics. Journal of Science Teachers' Association of Nigeria, 31(1), 27-33.

Sartor, L., and Young Brown, M. (2004). Consensus in the classroom: fostering a lively learning community. Mt. Shasta, CA: Psychosynthesis Press.

Schutt, R. (2001). Notes on consensus decision-making. [PDF document]. Retrieved from http://www.vernalproject.org/papers/process/ConsensNotes.pdf

Slavin, R. (1996). Research on cooperative learning and achievement: what we know, what we need to know. Contemporary Educational Psychology, 21, 43-69. 
Tzu-Ling Wang, M.S. (2008). Brain hemispheric preferences offourth-and fifth-grade science teachers and students in Taiwan: An investigation of the relationships to student spatial and verbal ability, student achievement, student attitudes, and teaching practice.

Dissertation Presented in Partial Fulfillment of the Requirements for the Degree of Doctor of Philosophy in the Graduate School of The Ohio State University

Ukoh, E.E and Adejimi, A.S. (2018). Analogy and guided inquiry instructional strategies and students' achievement in basic science in Lagos Metropolis, Nigeria: way forward for effective science teaching and learning. Journal of Education, Society and Behavioural Science, 26(1), 1-12, DOI: https://www.doi.org/10.9734/JESBS/2018/41378

Usman, I. A. (2008). Using a Selected Method of Teaching in Enhancing Slow Learners Academic Performance Among Junior Secondary School Integrated Science Students.

Vilia, P.N, Candeias, A.A, Neto, A.S, Franco, M.S and Melo, M. (2017). Academic achievement in physics-chemistry: the predictive effect of attitudes and reasoning abilities. Frontiers in psychology, 8, 1064. DOI: https://www.doi.org/10.3389/fpsyg.2017.01064

Walker, D, Greenwood, C, Hart, B and Carta, J. (1994). Prediction of school outcomes, based on early language production and socioeconomic factors. Child Development, 65, 606-621. DOI: https://www.doi.org/10.2307/1131404

Widhiarso, W and Haryanta (2016). Comparing the performance of synonym and antonym tests in measuring verbal abilities. TPM, 23(3), 335-345. DOI:

https://www.doi.org/10.4473/TPM23.3.5

Wolk, S. (1998). A democratic classroom. Portsmouth: Heinemann.

Wood, W. B., \& Gentile, J. M. (2003). Teaching in a Research Context. Science, 302(5650), 1510. https://doi.org/10.1126/science.1091803 